Dr DRAGAN BOGETIĆ, naučni savetnik

Institut za savremenu istoriju

UDK 327(497.1:450)"1974"(093.2)

Beograd, Trg Nikole Pašića 11

327(73)"1974"(093.2)

\title{
TRŠĆANSKA KRIZA 1974. I POGORŠANJE JUGOSLOVENSKO-AMERIČKIH ODNOSA*
}

\begin{abstract}
APSTRAKT: $U$ članku je analiziran uticaj obnavljanja graničnog spora između Jugoslavije i Italije na jugoslovensko-američke odnose. Aktuelizovanje dileme oko dugoročne održivosti provizornog rešenja u pogledu Trsta sankcionisanog Londonskim memorandumom, iskomplikovalo je odnose Jugoslavije sa njenim ključnim trgovinskim partnerom - Italijom, ali i saradnju sa SAD, bez koje je bila teško održiva jugoslovenska politika ekvidistance prema suprotstavljenim blokovima.
\end{abstract}

KLJUČNE REČI: Jugoslavija, Italija, SAD, Tršćanska kriza, Tito, Aldo Moro, razgraničenje, vojni manevri, NATO

Tokom proleća 1974. godine odigravaju se događaji koji će dodatno iskomplikovati aktuelna nastojanja zvaničnika iz Beograda i Vašingtona za unapređenjem bilateralne saradnje. Upravo u to vreme ponovo dolazi do eskalacije tršćanske krize i oštre jugoslovensko-italijanske konfrontacije oko nekadašnje Zone B. Ono što je naročito izazivalo veliku dozu ogorčenja u Beogradu, bilo je učešće američke Šeste flote zajedno sa italijanskim oružanim snagama u manevrima u severnom Jadranu, nadomak Trsta. Uključivanje Amerikanaca u ove manevre u Beogradu je tumačeno kao namerna provokacija i američka podrška italijanskim teritorijalnim pretenzijama prema Jugoslaviji.

Povod za novo zaoštravanje jugoslovensko-italijanskih odnosa, koje je u mnogo čemu podsećalo na burna politička i vojna previranja u vreme eskalacije tršćanske krize tokom 1953. godine, bilo je jugoslovensko postavljanje metalnih tabli sa natpisom „SFR Jugoslavija - SR Slovenija“ na graničnim prelazima prema Italiji u oblasti Kopra i Buja koja je nekada pripadala

* Rad je deo projekta Srpsko društvo u jugoslovenskoj državi u 20. veku: između demokratije i diktature, (177016), koji finansira Ministarstvo prosvete, nauke i tehnološkog razvoja Republike Srbije. 
Zoni B. Ovo nije bilo prvi put da Jugoslavija pribegne ovakvom rešenju u cilju konačne inkorporacije Zone B u sastav jugoslovenske teritorije. Deset godina ranije, oktobra 1964, Jugoslavija je takođe postavila slične table. Doduše, one nisu bile metalne i na njima je pisalo samo - „Državna granica“. Ali, posle protesta Italije, Jugoslavija je uklonila ove table. Ovaj put, zvanični Beograd nije bio spreman na popuštanje. ${ }^{1}$

Kao i ranije, otpočeo je svojevrstan „rat notama“. Prvo je italijanska vlada uputila Jugoslaviji dve oštre protestne note (15. februara ${ }^{2}$ i 11. marta $1974^{3}$ ) u kojima je upozorila jugoslovenske vlasti da postavljanje metalnih ploča „nema osnovu ni u jednom sporazumu u materiji sa italijanskom vladom i da je u suprotnosti sa Ugovorom o miru i Londonskim memorandumom o saglasnosti od 5. oktobra 1954. godine“; „da jugoslovenski suverenitet nikada nije bio proširen na italijansku teritoriju označenu kao Zona B“ i „da je nedopustiva svaka jednostrana promena postojećeg status kvoa između Italije i Jugoslavije“." Italijani su upozoravali svog suseda da demarkaciona linija uspostavljena Londonskim memorandumom nije ujedno i granična linija između dve zemlje i da zato na tom prostoru Jugosloveni ne smeju da postavljaju ploče kojima se prejudicira konačno razgraničenje.

Jugoslovenska vlada je u svojoj noti od 15. marta ovakve stavove Italijana okarakterisala kao „grubo mešanje u unutrašnje poslove SFRJ i napad na njen suverenitet i teritorijalni integritet", kao „otvorene teritorijalne revandikacije na delove SFRJ“ i „pokušaj revizije mirovnih ugovora zaključenih posle Drugog svetskog rata". ${ }^{5}$

Ubrzo je usledio italijanski odgovor. U noti od 19. marta, italijanska vlada je još eksplicitnije insistirala na provizornosti Memoranduma o saglasnosti i pravnoj neutemeljenosti jugoslovenskih optužbi. ${ }^{6}$

Već narednog dana, 20. marta 1974, u Beogradu je održana sednica Saveznog izvršnog veća, na kojoj su donete važne odluke, koje će činiti srž

${ }^{1}$ Massimo Bucarelli, Zakasnelo prijateljstvo - italijansko-jugoslovenski odnosi u drugoj polovini dvadesetog veka - 1947-1992, Tokovi istorije, br. 3/2012, 13-36; Saša D. Mišić, Politički odnosi Jugoslavije i Italije u periodu od 1968. do 1975. godine, doktorska disertacija odbranjena 13. marta 2013. na Fakultetu političkih nauka u Beogradu.

${ }^{2}$ DA MSP RS, 1974, PA, Italija, f-58, 48 276. Telegram Ambasade SFRJ u Rimu Saveznom sekretarijatu za inostrane poslove, 23. februar 1974.

${ }^{3}$ Isto, PA, Italija, f-58, 410 915. Telegram Ambasade SFRJ u Rimu Saveznom sekretarijatu za inostrane poslove, 11. mart 1974.

${ }^{4}$ Tekst nota italijanske vlade povodom postavljanja tabli na graničnim prelazima prema Italiji i jugoslovenske note videti u: Borba, 16. mart i 5. april 1974.

5 DA MSP RS, 1974, PA, Italija, f-58, 412 231. Najnoviji razvoj jugoslovenskoitalijanskih odnosa.

${ }^{6}$ Isto, 412472. 
buduće politike Jugoslavije u sklopu rešavanja graničnog spora sa Italijom. ${ }^{7}$ Odlučeno je da se spor sa Italijom internacionalizuje i to na taj način što će jugoslovensko ministarstvo inostranih poslova naložiti jugoslovenskoj delegaciji na Konferenciju o evropskoj bezbednosti i saradnji, koja se upravo održavala u Ženevi, da upozna učesnike tog skupa sa svim detaljima u vezi sa jugoslovensko-italijanskim sporom. Budući da je jedna od ključnih tema kojima se bavila Konferencija u Ženevi bilo upravo pitanje nepovredivosti granica, jugoslovenski predstavnici su trebali da skrenu pažnju ostalim delegatima na ,italijanske pretenzije koje predstavljaju udarac ciljevima ove konferencije“ i ujedno i pokušaj "revizije“ stanja stvorenog posle Drugog svetskog rata. U tom smislu, Italija je jedina zemlja u Evropi koja otvoreno ispoljava teritorijalne pretenzije prema svojim susedima. Pored toga, jugoslovenskim diplomatskim predstavništvima širom sveta su date posebne instrukcije kako da obrazlože stavove svoje vlade o novonastalom problemu. Tu su posebnu ulogu trebala da odigraju diplomatska predstavništva u Velikoj Britaniji i SAD, zemljama koje su učestvovale u potpisivanju i bile garant punovažnosti Memoranduma o saglasnosti iz 1954. U sklopu internacionalizacije spora sa Italijom, odlučeno je da se spor iznese i pred Ujedinjene nacije i u tom smislu trebalo je o tome uručiti posebno pismo samom generalnom sekretaru svetske organizacije Kurtu Valdhajmu. ${ }^{8}$

Posebna pažnja tokom pomenute sednice SIV-a poklonjena je merama koje treba preduzeti na unutrašnjem planu kako bi se na pravi način odreagovalo na italijansku kampanju. U tom smislu, „društvenopolitičkim organizacijama“ naloženo je da preduzmu „odgovarajuće aktivnosti“ da bi se šira jugoslovenska javnost što bolje upoznala sa novonastalom situacijom i podstakla na akciju. Rezultati ovakve strategije mogli su se vrlo brzo osetiti. „Aktiviranje“ domaće javnosti usledilo je vrlo brzo. Nije prošlo ni nekoliko dana od sednice SIV-a, a širom zemlje su započele „spontane" manifestacije i javni protesti protiv italijanske vlade. Presudnu ulogu u tom sklopu imala su informativna sredstva, u prvom redu - štampa. Već od 22. marta ove aktivnosti poprimaju obrise dobro sinhronizovane i koordinisane kampanje. Štampa i televizija na udarnim mestima objavljivali su vesti o sporu sa Italijom i sve to bogato ilustrovali fotografijama sa protestnih mitinga na kojima su dominirale parole podrške jugoslovenskom rukovodstvu. Na tim mitinzima, ali i u stotinama pisama upućenim Titu, uz oštre proteste sve više se izražava spremnost da se oružjem brani suverenitet Jugoslavije. Pri tome se naročito vodilo računa da se naglasi postojanje

\footnotetext{
${ }^{7}$ AJ, PR, I-5-b/44-17. Informacija o jugoslovensko-italijanskim odnosima, 21. mart 1974.

${ }^{8}$ DA MSP RS, 1974, PA, Italija, f-58, 414 643. Dopis SIV upućen SSIP-u 29. marta 1974; Isto, f-58, 412 478. Ambasadama SFRJ u Moskvi, Vašingtonu, Londonu, Parizu, Misiji pri UN u Njujorku, 22. mart 1974.
} 
punog jedinstva svih aktera protesta i jedinstvo jugoslovenskog rukovodstva. Protesti se odigravaju u svim delovima zemlje i u njima učestvuju građani svih profesija i svih starosnih doba (studenti zajedno sa profesorima, radnici, ostareli borci, seljaci, vojne starešine i pripadnici svih redova vojske). ${ }^{9}$

Krajem marta 1974. jugoslovensko-italijanski spor sve više poprima obrise ozbiljnog sukoba na relaciji Jugoslavija - NATO. Do ovakvog obrta dolazi zbog manevara amfibijskih snaga NATO-a u oblasti Tršćanskog zaliva. Plan za održavanje ovih vojnih manevara sačinjen je godinu dana ranije i jugoslovenske vlasti su bile blagovremeno upoznate sa tim planom. Pa ipak, zvaničnici iz Beograda su optužili SAD i NATO da su se, opredeljujući se za ovu akciju, upravo u momentu kada je kriza na ovom prostoru opasno eskalirala, svrstali na italijansku stranu. Od tog momenta spor između Jugoslavije i Italije dobija novu, širu dimenziju i još ozbiljniji karakter.

Jugoslovenski ambasador u Vašingtonu Toma Granfil, povodom manevara italijanskih oružanih snaga i američke Šeste flote $u$ severnom Jadranu u rejonu Trsta, uputio je 25. marta 1974. oštro upozorenje jugoslovenske vlade Velsu Stableru (Wels Stabler), pomoćniku državnog sekretara za Evropu u Stejt departmentu i zatražio objašnjenje o pozadini ovakvog poteza SAD. Sa američke strane strane izraženo je „žaljenje što je došlo do problema između dve zemlja sa kojima SAD imaju prijateljske odnose" i iskazana nada da će se tu uskoro naći pozitivno rešenje. Pri tome, izostao je bilo kakav komentar $\mathrm{u}$ vezi sa američkim uplitanjem $\mathrm{u}$ jugoslovenskoitalijanski konflikt. ${ }^{10}$

Dva dana kasnije, taj problem je bio tema žive diskusije između američkog ambasadora Malkolma Tuna (Malcolm Toon) i zamenika jugoslovenskog ministra inostranih poslova Jakše Petrića. Tun je uveravao Petrića „da niukom slučaju ne može biti reči o tome da NATO stoji iza italijanske interpretacije spora“, već o „nesretnoj koincidenciji“. Manevri su planirani već odavno i ,između njih i italijanske note ne postoji nikakva povezanost", naglasio je Tun. Petrić nije prihvatao ovakvu argumentaciju. Manevri su, po njemu, mogli biti ranije planirani, jer je ranije isplanirano i donošenje italijanske note. U tom smislu, Petrić je postavio pitanje: „zašto je u ovom trenutku, nakon 20 godina, italijanska vlada našla za potrebno da otvoreno istupa sa teritorijalnim pretenzijama“. Budući da su u jugoslovenskim političkim krugovima bile poznate procene Stejt departmenta o oslabljenoj međunarodnoj poziciji Jugoslavije zbog dezintegracionih procesa $u$

${ }^{9}$ S. D. Mišić. n. d., 298-299; AJ, KPR; I-5-b/44-17. Informacija o jugoslovenskoitalijanskim odnosima do 30. marta 1974. g; Isto. Informacija o telegramima upućenim Predsedniku Republike povodom nota italijanske vlade.

${ }^{10}$ AJ, KPR, I-3-a/107-210. Jugoslovensko-italijanski odnosi. Stav SAD. 
zemlji i Titovog narušenog zdravlja, ${ }^{11}$ Petrić se takođe zapitao nije li italijanski nastup „povezan sa nekim procenama o međunarodnom položaju Jugoslavije". ${ }^{12}$

Tokom narednih dana u Jugoslaviji otpočinje oštra novinska kampanja protiv SAD zbog vojnih manevara u severnom Jadranu. U tom duhu, karakterističan je članak objavljen 3. aprila na prvoj strani Borbe, naslovljen "Manevri pritiska“. Američko-italijanski manevri su u ovom redakcijskom uvodniku okarakterisani kao „opasno povampirenje strašila iz Hladnog rata" u cilju „zastrašivanja jedne miroljubive i nesvrstane zemlje". Pri tome, u članku se nedvosmisleno ukazuje na političku pozadinu ove „mračne predstave“. Ona se održava "pod okriljem i amblemima NATO pakta, organizacije sa petnaestak zemalja-članica, čije vlade izgleda još uvek nisu dovoljno svesne koliko ih ovo paradiranje krstarica - u sadašnjoj i ovakvoj situaciji - stavlja u izuzetno delikatan položaj. Naime, manevri u Jadranu se ne vrše prema nekom drugom bloku ili paktu, već prema granicama nesvrstane i miroljubive Jugoslavije koja je toliko mnogo učinila da se jadranske vode sve češće i više spominju kao 'more mira'. Pojava Šeste flote $u$ ovom delu Mediterana, po prvi put na vojnim manevrima, uz otezanje sa prisustvom u Tršćanskom zalivu, opasan je i događaj i presedan: u znatno širim evropskim razmerama". ${ }^{13}$

Već narednog dana, posle objavljivanja ovog članka, predstavnik američke ambasade zatražio je prijem u jugoslovenskom ministarstvu inostranih poslova, kako bi izrazio protest zbog ovakvog „netačnog izveštavanja“ jugoslovenske štampe o vojnim manevrima u severnom Jadranu. Posebno mu je smetalo to što se u Borbi navodi da se radi o "prvim" manevrima ove vrste u tom delu Jadranskog mora, iako je takvih manevara bilo i ranije, što je inače dobro poznato jugoslovenskim vlastima. Da su to stvarno bili prvi ovakvi manevri, onda bi to imalo nekog značaja. Plasiranje ovakvih netačnih podataka, Amerikanci su tumačili svesnom namerom jugoslovenskih zvaničnika da se predimenzionira značaj jedne rutinske vojne vežbe i uveri sopstvena javnost da se u susedstvu dešava nešto dramatično. Što se tiče kasnijeg kraćeg zadržavanja američke flote u Tršćanskoj luci po završetku vežbe, američki diplomata je objasnio da je ambasador Tun pokušao da ubedi učesnike manevara da brodovi odu u neku drugu luku a ne Trst, ali je to odbačeno, jer bi to značilo odustajanje od ranijeg dogovora, što bi svakako naišlo na negativan prijem kod italijanske vojne komande i vlade. S dru-

${ }^{11}$ Dragan Bogetić, Američke analize budućnosti Jugoslavije posle Tita s početka 70-tih godina, Tokovi istorije, br. 1/2012, Beograd 2012, 159-174.

${ }^{12}$ AJ, KPR, I-5-b/104-19. Zabilješka o razgovoru zamjenika saveznog sekretara J. Petrića sa ambasadorom SAD M. Toon-om, 27. marta 1973.

${ }^{13}$ Borba, 3. april 1974. 
ge strane, tu se radilo o rutinskoj odluci, koja je bila prirodna s obzirom na prostorno određenje u kome je realizovana amfibijska vežba i koja ni na koji način nije bila uperena protiv Jugoslavije (američki brodovi su i ranije često bili usidreni u Tršćanskoj luci). Posle objavljivanja pomenutih novinskih komentara, američka ambasada u Beogradu poslala je saopštenje za jugoslovensku štampu, ali nijedan list nije to objavio, iako je, po mišljenju američkih diplomata, to bio najbolji način da se jugoslovenska javnost upozna sa stavom SAD. Ovako, ovaj spor se dalje zaoštrava „mimo američke kontrole“, iako bi američke vlasti želele „da se izađe iz ove situacije“, jer su zainteresovane za dobre odnose sa Jugoslavijom. Stoga je prilog, koji nisu htele da objave nijedne novine u Jugoslaviji, ipak, uručen predstavniku jugoslovenskog ministarstva inostranih poslova. U njemu je ukazano da "s obzirom na ovdašnje očigledno pogrešno shvatanje cele stvari, svakako će biti korisno objasniti, da snage Sjedinjenih Država i Italije učestvuju u davno planiranim amfibijskim vežbama NATO-a malih razmera. Slične amfibijske vežbe NATO-a održavane su i u toku minulih godina u ovom istom kraju. One ni na koji način nisu $u$ vezi sa sadašnjim italijanskojugoslovenskim spornim pitanjem oko Trsta. Sjedinjene Države i dalje ostaju verne stavu koji smo zauzele 1954. godine kada su Italija, Jugoslavija, Velika Britanija i Sjedinjene Države potpisale Londonski memorandum o sporazumu u pogledu Slobodne Teritorije Trsta“. ${ }^{14}$

Za razliku od Amerikanaca, koji su vrlo energično reagovali na zbivanja u Jugoslaviji povodom manevara u severnom Jadranu, jugoslovenski saveznici iz Pokreta nesvrstanosti držali su se vrlo uzdržljivo i pasivno. O tome je redovno bilo obaveštavano jugoslovensko ministarstvo inostranih poslova u brojnim telegramima iz jugoslovenskih ambasada sa afro-azijskog i latino-američkog prostora. Tipičan je bio telegram iz Alžira, inače države poznate po radikalnim stavovima prema politici SAD i vojnim akcijama NATO-a. U tom telegramu se ukazuje na sklonost alžirskih zvaničnika da izbegnu bilo kakvo sporenje sa Italijom zbog Jugoslavije, jer bi na taj način mogli ugroziti ekonomsku saradnju sa Italijom, koja je od primarnog interesa za većinu mediteranskih država. Stoga, na pitanje jugoslovenskih diplomata: „Zašto ne reaguju i zašto ne osude Italijane zbog njihovih teritorijalnih aspiracija prema Jugoslaviji“, Alžirci su se opravdavali da im je teško da se na pravi način postave, jer se tu radi o širem problemu, proizašlom iz agresivne politike zapadnih sila i da je, zapravo, glavni krivac Amerika i NATO, jer im smeta nesvrstanost i međunarodna pozicija Jugoslavije. ${ }^{15}$

${ }^{14}$ DA MSP RS, 1974, PA, Italija, f-58, 415 523. Zabeleška o razgovoru D. Grubora, zamenika načelnika IV uprave sa D. Tice, savetnikom ambasade $S A D$, 4. april 1974.

${ }^{15}$ DA MSP RS, 1974, PA, Italija, f-59, 424 798. Telegram ambasade SFRJ u Alžiru Saveznom sekretarijatu za inostrane poslove, 20. maj 1974. 
Ni Sovjeti nisu ispoljavali neku naročitu spremnost da podrže Jugoslaviju u njenom sporu sa Italijanima i Amerikancima. I oni su se tu, naravno, rukovodili sopstvenim interesima i nastojanjima da ne ugroze bipolarni detant. U izveštaju jugoslovenskog ministarstva inostranih poslova, naslovljenom „Reagovanje u evropskim socijalističkim zemljama na najnoviji razvoj jugoslovensko-italijanskih odnosa“, ukazano je na to „rezervisano“ i „pasivno“ držanje Kremlja. Ono je posebno dolazilo do izražaja tokom prve faze spora - „nije bilo ni internih, niti javnih reagovanja i komentara, niti natpisa u štampi“. Nešto kasnije, SSSR je reagovao tako što je govorio „da je iznenađen italijanskom akcijom i da se pita koji su razlozi naveli italijansku vladu da u vreme detanta i KEBS-a istupa na ovaj način“. Posle dalje eskalacije spora, SSSR je konačno izneo svoj zvaničan stav „da nema govora o menjanju posleratnih granica i da do toga može doći samo putem rata, što je malo verovatno u sadašnjim uslovima“. U tom smislu je naglašavano da „što se tiče SSSR, pitanje jugoslovensko-italijanske granice je rešena stvar... Mirovni ugovor sa Italijom i Londonski sporazum predstavljaju deo evropskog uređenja posle Drugog svetskog rata“. Sovjetsko insistiranje na „nepromenljivosti“ evropskih granica (za razliku od stava Zapada o "nepovredivosti“" granica) predstavljalo je, zapravo, sovjetski odgovor na svaki eventualni pokušaj da se dovedu u pitanje granice prema Nemačkoj. ${ }^{16}$

U jugoslovenskom ministarstvu inostranih poslova su smatrali da je razvoj situacije primorao Sovjete da, makar, deklarativno podrže Jugoslaviju, ali da pri tome čine sve što je u njihovoj moći da ubede jugoslovenske zvaničnike da odustanu od daljeg zaoštravanja spora. Taj pokušaj „da nas smiruju“, posebno je dolazio do izražaja u sovjetskim upozorenjima „da treba voditi računa da nas protivnička strana ne isprovocira“, „da ne treba isključiti mogućnost italijanskog pokušaja da se Jugoslavija prikaže kao faktor koji otežava sporazumevanje i saradnju u Evropi“. Ovakva dozirana i uslovljena sovjetska podrška dolazila je do izražaja i u napisima u sovjetskoj štampi. Naime, tu su, doduše, bile prenošene izjave jugoslovenskih zvaničnika i pisanje jugoslovenske štampe, ali nisu davani nikakvi komentari. Ovakav prilaz, takođe, dolazio je do izražaja i tokom svih razgovora vođenih između jugoslovenskih i sovjetskih zvaničnika. U tim razgovorima Sovjeti su ukazivali na to da se radi o "neprijatnoj stvari“ i "da ne veruju da iza ove provokacije stoji Niksonova administracija, jer situacija koja bi nastala daljim pogoršanjem jugoslovensko-italijanskih odnosa ne bi mogla da ostane bez posledica na sovjetsko-američke odnose i na dosadašnji trend popuštanja u Evropi i šire“. Ambasador SSSR-a na Konferenciji o evropskoj bezbednosti i saradnji, Mendeljevič, upozorio je Jugoslovene da su Sovjeti „bili

${ }^{16}$ DA MSP RS, 1974, PA, Italija, f-58, 415 576. Reagovanje u evropskim socijalističkim zemljama na najnoviji razvoj jugoslovensko-italijanskih odnosa. 
zabrinuti i iznenađeni našim istupanjem na KEBS-u i interesovao se da li je naša delegacija ovo pitanje pokrenula samoinicijativno ili po instrukcijama vlade. Izneo da bi insistiranje na daljem razmatranju ovog problema na KEBS moglo komplikovati dalji tok Konferencije". Istovremeno, sovjetski predstavnik je istakao da je njegova vlada „zadovoljna blagom reakcijom Italijana“. Pored svih ovih negativnih opaski na račun sovjetskog držanja u aktuelnoj situaciji, u izveštaju se navodi da SSSR želi da tu situaciju iskoristi i za „svojevrstan pritisak u pravcu približavanja nekih naših stavova sovjetskim stavovima (pitanje granica, dokumenti KEBS-a)“. ${ }^{17}$

Pa ipak, zvanični Beograd nije odustao od svojih nastojanja da iskoristi KEBS kao pogodnu tribinu za internacionalizaciju svog spora sa Italijom i predstavi Italiju kao državu koja dovodeći u pitanje granicu prema svom susedu - dovodi u pitanje osnovna načela za koja se Konferencija zalaže. Stavovi iz platforme, usvojeni na sednici Saveznog izvršnog veća 20. marta 1974, i dalje su činili okosnicu jugoslovenske politike prema Italiji. ${ }^{18}$

Mesec dana posle početka krize, konačno se oglasio i sam Josip Broz. To je učinio tokom boravka u Sarajevu i razgovora sa tamošnjim rukovodstvom. Obraćajući se predstavnicima društveno-političkih organizacija u Sarajevu, 15. aprila 1974, izložio je svoje mišljenje o teritorijalnim pretenzijama Italije i italijansko-američkim vojnim manevrima u Jadranu. „Ovaj pritisak na nas nije slučajan, to nije samo stvar Italije, to je stvar i Atlantskog pakta. Nisu Amerikanci slučajno sa njima izvodili manevre tu, na Jadranu, pred našim nosom, na našoj granici“. Elaborirajući tezu da je Jugoslavija "tačka na koju se vrše pritisci“, Tito je dao i svoje tumačenje pozadine takvog stanja: „Vi znate da je bilo raznih pričanja. Neki su pisali da sam ja šlogiran, pisali su ovo i ono... A takvi stalno čekaju da do nečega dođe u Jugoslaviji, da se ona pocijepa, raspadne, ne bi li šta dobili““. ${ }^{19}$

Novinska kampanja u Jugoslaviji protiv SAD i Titov govor u Sarajevu uzrokovali su izuzetno negativne reakcije u SAD. Pomoćnik državnog sekretara za Evropu Vels Stabler pozvao je jugoslovenskog ambasadora u Vašingtonu Tomu Granfila i ponovo mu izložio stavove svoje vlade $u$ vezi aktuelnog spora. Upozorio ga je da su jugoslovenske optužbe u potpunosti neutemeljene i da se zvanični Vašington odlučno protivi davanju podrške bilo čijim teritorijalnim pretenzijama. ${ }^{20}$

${ }^{17}$ Isto.

${ }^{18}$ DA MSP RS, 1974, PA, Italija, f-58, 417 529. Obnavljanje pretenzija Italije na bivšu Zonu $B$ i program naših daljih akcija.

${ }^{19}$ Predsednik Tito govori predstavnicima društveno-političkih organizacija Sarajeva, Borba, 16. april 1974.

${ }^{20}$ DA MSP RS, 1974, PA, Italija, f-58, 417 529. Reagovanje SAD na najnoviji razvoj jugoslovensko-italijanskih odnosa, 10. april 1974. 
Predstavnici američke ambasade $u$ više navrata su izražavali svoje nezadovoljstvo pisanjem jugoslovenske štampe o manevrima u severnom Jadranu. Ukazivali su na netačnost navoda da ti manevri predstavljaju bilo kakav oblik pritiska na Jugoslaviju i da se takvi manevri u kojima učestvuje Šesta flota prvi put organizuju upravo u tom delu Mediterana (slični manevri u kojima je američka Šesta flota učestvovala su organizovani i ranije). ${ }^{21}$

Ambasador Tun je u pismu pomoćniku ministra za inostrane poslove Raifu Dizdareviću, 5. aprila, izrazio svoju „uznemirenost“ zbog komentara u jugoslovenskoj štampi, na radiju i televiziji o manevrima NATO-a i „tobožnjoj američkoj podršci Italiji“. Istakao je da bi u slučaju da su manevri otkazani - Italijani to tumačili kao podršku Jugoslaviji. Obe strane, i Jugoslavija i Italija, zbog problema koje imaju na unutrašnjem planu svesno doprinose eskalaciji spora, smatrao je ambasador. Jugoslavija to čini kako bi „veštački ojačala jedinstvo“ među republikama, a Italija radi privremene podrške ekstremnih krugova „klimavoj vladi“. ${ }^{22}$

Da su jugoslovenska strahovanja o unapred isplaniranom i koordinisanom sadejstvu američke i italijanske vlade u vreme eskalacije tršćanske krize bila u celini neopravdana i bezrazložna, pokušao je da uveri jugoslovenske diplomate i američki državni sekretar Henri Kisindžer (Henry Kissinger). Dobra prilika za to ukazala se tokom Šestog specijalnog zasedanja Generalne skupštine UN, kome je pored američkog državnog sekretara, prisustvovao i jugoslovenski ministar inostranih poslova Miloš Minić.

Bez obzira na evidentnu razliku u stavovima ove dvojice ministara oko uzroka i modaliteta razrešenja energetske krize kojoj je bilo posvećeno pomenuto vanredno zasedanje Generalne skupštine i bez obzira na činjenicu da je tokom prethodnog redovnog zasedanja svetskog parlamenta Kisindžer odbio da se susretne sa Minićem (zbog Minićevih optužbi na račun SAD u vezi sa državnim udarom u Čileu) - dvojica diplomata su ovaj put pokazala zavidan stepen kooperativnosti.

Tokom razgovora, vođenog 15. aprila 1974. u sedištu UN, nezaobilazna tema, naravno, bio je problem koncipiranja nove platforme na kojoj bi se ubuduće zasnivali odnosi između industrijski razvijenih zemalja i zemalja u razvoju. Kisindžer je ovaj razgovor otvorio stavljajući u prvi plan pozitivne efekte inicijative nesvrstanih zemalja tokom Šestog specijalnog zasedanja Generalne skupštine i ispoljavajući određeno razumevanja za jugoslovenske stavove o tom pitanju. Istakao je „da kao osnovni principi jugoslovensko-američkih odnosa ostaju da važe oni koji su postavljeni tokom sastanaka predsednika Niksona i Tita u Beogradu i Vašingtonu“. U

\footnotetext{
${ }^{21}$ AJ, PR, I-3-a/107-210.

${ }^{22}$ AJ, PR, I-3-a/107-211. Jugoslovensko-italijanski odnosi. Stav SAD.
} 
tom smislu, Kisindžer je, čak, dva puta ponovio „da vidi jugoslovensku nesvrstanost, kao pozitivan doprinos svetskom miru“. ${ }^{23}$

Minić je ovo pozitivno primio - rekao je da ceni ova uveravanja i da će ih preneti svojoj vladi. Upozorio je Kisindžera da su ta uveravanja "posebno značajna sada, u momentu kada je jugoslovenska javnost uznemirena zbog nekih iznenađujućih koincidencija“. Postepeno je težište razgovora prebacivao na glavni problem u jugoslovensko-američkim odnosima. Naglasio je da „bismo bili mnogo srećniji da u ovom momentu nije došlo do manevara Šeste američke flote u neposrednoj blizini naših granica" i da je još veću zabrinutost u Jugoslaviji izazvalo to „što su ti brodovi posle manevara otišli u Trst. To je, hteli mi to ili ne, poprimilo karakter vojnog pritiska na Jugoslaviju“. Istakao je da to „nije samo naš utisak, nego i mnogih drugih u Evropi i u svetu“. ${ }^{24}$

Kisindžer je negirao da SAD vrše bilo kakav pritisak na Jugoslaviju svojim učešćem u manevrima na severnom Jadranu. Stalno je ponavljao da američka „pomorska akcija u oblasti Trsta nema nikakve veze sa jugoslovensko-italijanskim sporom“. ${ }^{25}$ Objasnio je „da u slučajevima kad SAD negde vrše vojni pritisak, on o tome obično biva obavešten. U ovom konkretnom slučaju nije uopšte znao gde idu brodovi posle manevara. Radi se o rutinskoj odluci mornarice". Uveravao je Minića da to nema nikakvu političku pozadinu, ali mu se činilo opravdanim i to „što smo mi to mogli shvatiti kao pritisak“. Dodao je, kao u šali, „da ne bi trebalo da pojačavamo naš obalni odbrambeni sistem protiv američke mornarice, jer bi to bilo nepotrebno trošenje sredstava“. Minić je, reagujući na ovu upadicu, upitao Kisindžera: „šta bi on uradio na našem mestu, u situaciji ovolikog broja nepoželjnih koincidencija“, na šta je ovaj odgovorio: „To je pravo pitanje“, ali je potom dodao „da je odgovor na njega već pošteno dao“. Izjavio je „da se SAD neće uplitati u naš spor sa Italijom oko Trsta i nikakve vojne manifestacije u Jadranu neće sprovoditi koje bi mogle ličiti na zastrašivanje". Smatrao je potrebnim da napomene „da je dosadašnja aktivnost SAD na Jadranu bila više usmerena na zaštitu Jugoslavije" nego na neku suprotnu opciju. Doduše, odmah se ogradio da Jugoslavija nije nikada takvu zaštitu tražila „ali je bilo momenata kada su SAD o tome razmišljale“. Po već usta-

${ }^{23}$ FRUS, 1969-1976, Volume E-15, Part 1, Documents on Eastern Europe, 19731976, Yugoslavia, doc 68. Telegram From the Department of State to the Embassy in Yugoslavia, April 17, 1974. US-Yugoslav bilateral Relations; AJ, KPR, I-4-c/2-19.

${ }^{24}$ DA MSP RS, 1975, PA, SAD, f-124, 418 133. Zabeleška o razgovoru potpredsednika SIV-a i saveznog sekretara za inostrane poslove M. Minića sa državnim sekretarom za inostrane poslove SAD H. Kisindžerom, 15. aprila 1974. u Njujorku.

${ }^{25}$ FRUS, 1969-1976, Volume E-15, Part 1, Documents on Eastern Europe, 19731976, Yugoslavia, doc 68. Telegram From the Department of State to the Embassy in Yugoslavia, April 17, 1974. US-Yugoslav bilateral Relations. 
ljenom klišeu, Minić je precizirao „da mi zaštitu ne tražimo ni od koga“ i da „ukoliko dođe do agresije i rata protiv nas, to će biti opštenarodni rat naroda Jugoslavije kakav smo vodili i u nedavnoj prošlosti“. Ipak, zahvalio se Kisindžeru na iskazanoj spremnosti SAD da pruže podršku Jugoslaviji ukoliko bi njen suverenitet bio ugrožen. U datoj situaciji, smatrao je da bi poželjnije bilo da se zajedničkim naporima Jugoslavije i SAD „poprave štetne posledice za naše bilateralne odnose koje su proizašle iz pomenutih okolnosti“. Tu je, pre svega, imao u vidu intenziviranje ličnih kontakata zvaničnika dveju država. „Naprimer, planirana, pa odložena, poseta ministra trgovine Denta ili konsultacije Vašeg zamenika Raša“. Ovu inicijativu podržao je Kisindžer, smatrajući da će dogovor s tim u vezi biti lako postići. Obećao je da će se i sam lično angažovati i sugerisao Miniću da jugoslovenska ambasada u Vašingtonu to konkretizuje. Još jednom je naglasio da, kada je reč o sporu Jugoslavije i Italije, SAD ne podržavaju teritorijalne zahteve Italije i izneo svoj utisak da takvi zahtevi neće još dugo biti forsirani, jer su uslovljeni momentalnim unutrašnjim političkim okolnostima. Dodao je „da su, iskreno govoreći i SAD bile iznenađene" postupcima Italije i obećao „da će učiniti sve što mogu da se stvari stišaju“. Minić se složio sa Kisindžerom da je postupak Italije predstavljao svojevrsno iznenađenje, s obzirom na dugogodišnju prisnu jugoslovensko-italijansku saradnju, koja je nailazila na veliko uvažavanje u Evropi. U tom smislu, napomenuo je da Jugoslavija nema nikakvih teritorijalnih pretenzija ni prema Italiji ni prema bilo kojoj drugoj zemlji u Evropi i da pitanje svojih granica smatra definitivno rešenim. Stoga o tom pitanju nema uopšte nameru da razgovara sa Italijom, a da je na Italiji da ispravi ono što je učinila. ${ }^{26}$

U Beogradu je Kisindžerovo istupanje tokom razgovora sa Minićem ocenjeno kao veliki zaokret u politici SAD prema Jugoslaviji i kao pokušaj Amerikanaca da vrate odnose sa Jugoslavijom na "normalni kolosek“. Takav zaokret objašnjen je pojačanim respektom SAD prema Jugoslaviji zbog njenog relativno izbalansiranog nastupa u UN u sklopu borbe nesvrstanih zemalja za uspostavljanje novog međunarodnog ekonomskog poretka ( $\mathrm{u}$ odnosu na grupu „radikalnih“ nesvrstanih zemalja koje je predvodio alžirski predsednik Bumedijen). U duhu takvog tumačenja, Nikson i Kisindžer su procenili da je politika pritiska na Jugoslaviju tokom prethodne dve godine bila „pogrešna“ i „nije dala rezultate“, već sasvim suprotne efekte, posebno kada je reč o sporu Jugoslavije sa Italijom. Stoga je pogoršanje jugoslovensko-američkih odnosa išlo na ruku Sovjetima, a potencijalno nanosilo štetu Amerikancima, tim pre što je u pitanju bila jedna uticajna članica Pokreta

${ }^{26}$ DA MSP RS, 1975, PA, SAD, f-124, 418 133. Zabeleška o razgovoru potpredsednika $S I V$-a i saveznog sekretara za inostrane poslove M. Minića sa državnim sekretarom za inostrane poslove SAD H. Kisindžerom, 15. aprila 1974. u Njujorku. 
nesvrstanosti koja je igrala važnu ulogu u sklopu razrešenja krize na Bliskom istoku i koordinisane akcije nesvrstanih zemalja čiji je cilj bila radikalna transformacija postojećeg međunarodnog ekonomskog poretka. Jugoslovenski zvaničnici su razgovor Minića i Kisindžera ocenjivali kao „koristan“ i „konstruktivan“. Nastojanja američkog državnog sekretara da obezbedi atmosferu za normalizaciju bilateralnih odnosa uprkos Minićevoj kritičnosti na račun američkih „pritisaka“ i „iznenađujućih koincidencija“ u pogledu jugoslovensko-italijanskog spora, shvatili su kao američko prihvatanje Jugoslavije kao ravnopravnog partnera, proizašlo iz saznanja „da se pritisci ne isplate". ${ }^{27}$

Mada Kisindžer nije u potpunosti uspeo da ubedi Minića u pogledu stvarne pozadine američkog učešća u manevrima u severnom Jadranu, čini se da je njegovo obrazloženje ipak bilo iskreno i da je odražavalo stvarno raspoloženje unutar američkih političkih krugova. To se može zaključiti i na osnovu sadržine razgovora koji su na ovu temu u Vašingtonu narednog meseca vodili ambasador Malkolm Tun, Robert Elsvort (Elsworth), pomoćnik američkog ministra za odbranu i general H. Lobdel (Lobdell), direktor ministarstva za odbranu zadužen za Evropu. Iz samog tona i sadržaja razgovora vidi se da Amerikanci ni u kom slučaju nisu ranije isplanirali manevre u severnom Jadranu sa italijanskim pomorskim snagama, jer su znali da će Italija tokom marta ponovo pokrenuti pitanje Zone B. Odluku da se uključe u te manevre, uprkos eskalaciji jugoslovensko-italijanskog graničnog spora, doneli su teška srca, isključivo zbog toga što bi odlaganje tih manevara u Italiji bilo shvaćeno kao akt podrške Jugoslaviji. Svesni da će se u svakom slučaju zameriti ili Italiji, ili Jugoslaviji, Amerikanci su ipak dali prednost svom važnom savezniku iz NATO-a. Pa ipak, tokom razgovora, Tun je upozorio svoje sagovornike da treba razmotriti političke posledice manevara organizovanih u severnom Jadranu, u momentu kada je došlo do eskalacije tršćanske krize. Napomenuo je da „on ne bi voleo da se u doglednoj budućnosti tamo održavaju vežbe u koje su uključene američke vojne snage u Jadranu - bar dok Jugosloveni i Italijani ne pristupe pregovorima". Iako mu je Elsvort skrenuo pažnju da zbog političkih faktora Amerikanci ne mogu da odustanu od svojih redovnih vojnih vežbi, postignuta je generalna saglasnost da se Tunovo stanovište ubuduće ima $u$ vidu. ${ }^{28}$

U Stejt departmentu su procenjivali da spor između Beograda i Rima ide na ruku nastojanjima pojedinih političara u Jugoslaviji koji se protive otopljavanju jugoslovensko-američkih odnosa i podržavaju radikalne „antiimperijalističke“ stavove pojedinih članica Pokreta nesvrstanosti u

${ }^{27}$ DA MSP RS, 1975, PA, SAD, f-124, 418610

${ }^{28}$ FRUS, 1969-1976, Volume E-15, Part 1, Documents on Eastern Europe, 19731976, Yugoslavia, doc 69. Memorandum of Conversation, Washington, June 25, 1974. 
Ujedinjenim nacijama. Protagonisti tog radikalizma, po proceni zvaničnika iz Vašingtona, insistiraju na tome da je bezbednost i nezavisnost Jugoslavije u većoj meri ugrožena od Zapada nego od Istoka. Stoga se u američkim političkim krugovima sve više ispoljava interes za što skorijim razrešenjem jugoslovensko-italijanskog spora. ${ }^{29}$ Igrom okolnosti ovakav trend počinje da sve više dolazi do izražaja u praksi, zahvaljujući postepenom sazrevanju svesti obeju sukobljenih strana o štetnosti dalje eskalacije krize.

Naime, mesec dana posle otpočinjanja bilateralnog spora, rat notama između Jugoslavije i Italije ulazi u završnu fazu. U tom smislu, italijanska vlada je još 16. aprila 1974. uručila svoju poslednju notu Jugoslaviji. Ta nota je zapravo predstavljala odgovor na jugoslovensku notu od 30. marta. Iako se tekst ove note nije mnogo razlikovao od ranijih nota, ipak je njen ton bio znatno pomirljiviji. U tom smislu se može tumačiti i poruka da Italija „nema nikakvih teritorijalnih pretenzija prema SFRJ“ i da "poštuje demarkacionu liniju, jednako kao što poštuje državnu granicu“. ${ }^{30}$ Spor je otpočeo upravo stoga što je italijanska vlada insistirala na oštroj distinkciji pravnih i političkih implikacija formulacija „demarkaciona linija“ i „državna granica".

Posle ove note vrhunac krize $\mathrm{u}$ odnosima Jugoslavije i Italije je prošao. Ulazi se u završnu fazu razrešenja graničnog spora aktiviranjem tajnog pregovaračkog kanala. U taj mehanizam, zbog negativne reakcije italijanskog javnog mnjenja i nestabilnosti italijanske vlade, nije direktno uključeno italijansko ministarstvo inostranih poslova. Da je ovakvo rešenje bilo optimalno u postojećoj situaciji i da je jedino ono moglo da obezbedi redovne kontakte dve strane, pokazalo se tokom brojnih sastanaka koji su potom održani.

U neku ruku, ispravnost primene ovakve metodologije indirektno je potvrdio 28. septembra 1974. i sam italijanski ministar inostranih poslova (a nešto kasnije premijer), Aldo Moro, tokom sastanka sa jugoslovenskim kolegom Milošem Minićem, u sedištu UN u Njujorku. Odmah na početku razgovora Moro je skrenuo pažnju Miniću da, s obzirom na nesinhronizovanost političkog angažmana pojedinih članova vlade, uopšte nije detaljno upoznat sa delovanjem tog pregovaračkog „kanala“. Miniću ovakva upadica nije baš delovala ohrabrujuće. Upozorio je sagovornika da ga „zabrinjava da

${ }^{29}$ The National Archives, Foreign and Commonwealth Office, 28/2804. - Informacije jugoslovenskog ministarstva inostranih poslova su ukazivale na sve učestalije pritužbe članica NATO svom savezniku Italiji zbog zaoštravanja odnosa sa Jugoslavijom. Tim povodom je pripreman i poseban sastanak zapadne alijanse. Od italijanske vlade je zatraženo da u pismenoj formi informiše članice NATO-a o svom stavu. - AJ, KPR, I-5-b/44-17. Informacija o jugoslovensko-italijanskim odnosima, 26. april 1974.

${ }^{30}$ AJ, KPR, I-5-b/44-17. Verbalna nota, 16. april 1974. 
opet ne dođe do promene vlade, koja bi mogla da nas vrati na početak“ “ ${ }^{31}$ Ovde treba posebno skrenuti pažnju na jedan ozbiljan problem koji je sam po sebi (po proceni jugoslovenskih diplomata) bio značajno izvorište nestabilnosti i nepouzdanosti vlade u kojoj je Moro trebalo da ima ključnu ulogu. Radilo se o učestalim američkim pritiscima na Italiju povodom pitanja eventualnog učešća komunista i socijalista u novoj vladi. Taj „istorijski kompromis" i „skretanje unutrašnjeg razvoja Italije u levo“, nije bio prihvatljiv za Amerikance i stoga su oni u svojim javnim izjavama upozoravali na nepoželjnost takvog obrta (predsednik Ford je tu bio dosta eksplicitan tokom svoje posete Italiji, juna 1974; američki ambasador u Italiji i američki kongresmeni su se na sličan način izjašnjavali). Smatrali su da bi uključivanje komunista $u$ italijansku vladu „stimulativno delovalo na unutrašnja kretanja i procese i u drugima zemljama zapadne Evrope (Portugal, Francuska, eventualno Španija)“. S druge strane, to bi iskomplikovalo nastojanja SAD da otvore nove baze u Italiji u slučaju da aktuelna odluka Grčke o napuštanju NATO-a zbog Kiparske krize rezultira ukidanjem baza NATO-a $\mathrm{u}$ toj zemlja. ${ }^{32} \mathrm{U}$ jesen 1974. godine, jugoslovenske službe bezbednosti su došle do podataka koji su ukazivali na ozbiljna unutrašnja previranja u Italiji čiji bi epilog mogao biti državni prevrat desničarskih snaga uz pomoć policije i armije. Sudeći po tim podacima, podršku ovakvom prevratu bi pružile i Sjedinjene Američke Države, koje su se energično zalagale za odstranjivanje komunista iz italijanske vlade (budući da nisu bili uvereni da bi ovi ispoljili dovoljan stepen kooperativnosti prema zapadnom paktu). Posle povlačenja Grčke iz NATO-a, sredinom avgusta 1974, pojačao se interes Amerikanaca da Italija postane najjače uporište zapadne alijanse na Mediteranu. Nastojanja Alda Moroa usredsređena na formiranje „velike koalicije" demohrišćana i komunista ni u kom slučaju nisu bila kompatibilna sa ovakvim američkim planovima. ${ }^{33}$

Imajući sve ovo $u$ vidu, Minićeva podozrivost iskazana tokom razgovora sa Moroom činila se opravdanom. Ukoliko bi se jugoslovenske procene pokazale ispravnim, potencijalno je postojala opasnost da se zbog složenih odnosa u NATO-u dovede $u$ pitanje višemesečni trud čitavog tima diplomata iz Jugoslavije i Italije. To je, naime, bilo vreme kada su se dve strane uglavnom dogovorile oko svih spornih pitanja vezanih za jugoslovensko-italijanski spor. Postignut je načelan dogovor oko manjih teritorijalnih korekcija na obe strane. Za Italiju je bila od posebnog značaja korektura u severnom sektoru spornog područja, odnosno proširenje industrijske

${ }^{31}$ AJ, KPR, I-5-b/44-17. Zabeleška o razgovoru druga Miloša Minića sa ministrom inostranih poslova Italije, A. Morom, 28. septembra 1974. godine, u Njujorku.

${ }^{32}$ DA MSP RS, Italija, f-55, 449 901. Karakteristike italijanske spoljne politike.

${ }^{33}$ AJ, KPR, I-5-b/44-17. Unutrašnja situacija u Italiji. 
zone Trsta. Za Jugoslaviju je, pak, bilo najvažnije da italijanska vlada konačno prizna demarkacionu liniju koja je delila dve države kao definitivnu graničnu liniju. Tito i Moro su se dogovorili da treba potpisati bilateralni sporazum (a ne multilateralni kao što je bio Memorandum o saglasnosti) i da bi trebalo obezbediti povoljnu atmosferu za njegovu instrumentalizaciju tako što bi ga svečano obznanili tokom Konferencije o evropskoj bezbednosti i saradnji, koja je upravo ulazila u završnu fazu. Samim tim, ne bi se nametnuo nepoželjan zaključak da su preporuke ove konferencije naterala dve strane da konačno potpišu sporazum, nego sasvim suprotno, kako su Jugoslavija i Italija direktno ovim činom dale svoj doprinos oživotvorenju duha KEBS-a. ${ }^{34}$

Proces normalizacije jugoslovensko-italijanskih odnosa i konačnog razgraničenja dve države okončan je 10. novembra 1975, potpisivanjem Sporazuma Jugoslavije i Italije u malom primorskom mestu Osimo, udaljenom 15-tak kilometara od Ankone. Sporazum su potpisali jugoslovenski ministar inostranih poslova Miloš Minić i ministar inostranih poslova Italije Marijan Rumor. Tim sporazumom je definitivno utvrđena jugoslovenskoitalijanska granica. Praktično njime je samo formalno potvrđena konačna vlast obe države nad zonama koje su već bile njima priključene samim aktom potpisivanja Memoranduma o saglasnosti, oktobra 1954. godine. ${ }^{35}$

Potpisivanjem Osimskog sporazuma uklonjeno je još jedno izvorište jugoslovensko-američkih nesuglasica. Reakcija Vašingtona tim povodom je bila izuzetno pozitivna. U momentu kada je „Jadranski mir" već bio izvestan, predstavnik Stejt departmenta Robert Funset (Robert Funseth), na konferenciji za štampu, 2. oktobra 1975, izjavio je da dogovor dve vlade „odražava državnički pristup rukovodilaca obeju vlada u nastojanju da reše ovaj dugoročni problem" i „korak napred ka postizanju stabilnosti i bezbednosti u ovoj oblasti u Evropi“. Slične ocene dominirale su i u američkoj štampi. Ovaj događaj ocenjen je kao ,jedan od prvih rezultata u Samita Helsinkiju, koji je ublažio zategnutost između Istoka i Zapada i potvrdio princip da posleratne granice u Evropi ne mogu da se menjaju silom". U tom smislu, u američkoj štampi se često navodila i izjava Alda Mora, „da Italija želi nezavisnu, integralnu Jugoslaviju, jer je u ovakvim uslovima Italija branjena sa svoje istočne strane". ${ }^{36}$

${ }^{34}$ AJ, KPR, I-5-b/44-17. Zabeleška o razgovoru druga Miloša Minića sa ministrom inostranih poslova Italije, A. Morom, 28. septembra 1974. godine, u Njujorku.

${ }^{35}$ DA MSP RS, 1975, PA, Italija, f-55, 452 752. Ugovor između Socijalističke Federativne Republike Jugoslavije i Republike Italije („Zbirka međunarodnih ugovora“). - Sporazum je stupio na snagu 3. aprila 1977. razmenom ratifikacionih instrumenata (AJ, KPR, I-5b/44-18).

${ }^{36}$ DA MSP RS, 1975, PA, Italija, f-55, 448 154. Reagovanja zapadnih zemalja. 
Može se reći da su već tokom leta 1974. otklonjene jugoslovenskoameričke nesuglasice oko jugoslovenskog spora sa Italijom, a u Beogradu i Vašingtonu je optimistički procenjivano da je faza zahlađenja jugoslovensko-američkih odnosa definitivno okončana. ${ }^{37}$

Dragan Bogetić

\section{THE CRISES OVER THE TRIESTE 1974 AND DECLINE IN YUGOSLAV-AMERICAN RELATIONS}

\section{Summary}

This article analyzes of renewed border dispute between Yugoslavia and Italy in 1974, and its impact on the Yugoslav-American relations. The US approach to the Yugoslav-Italian dispute in 1974 about the border issue 1974 in the former Zone B, seriously jeopardized the relatively positive trend of relations between Belgrade and Washington, established during the period after Nixon's first visit to Belgrade in 1970 and Tito's visit to Washington in 1971. The appearance of the US Sixth Fleet in large Italian maneuvers in the northern Adriatic, near Trieste, Belgrade interpreted as a deliberate provocation and American support for Italian territorial claims against Yugoslavia. The Americans sharply reacted on the campaign that was waged in the Yugoslav press against the United States, and its support for Italy. The State Department had a strong belief that both sides, knowingly contribute to the escalation of the conflict, because of the internal problems. On one hand in Yugoslavia, conflict was used for artificial strengthening of unity among the republics and in Italy for temporary support to its „shaky government." Actualization of those dilemmas regarding the long-term sustainability of the tentative decision regarding Trieste and border issues, complicated the Yugoslav relations with Italy which was its key economical partner, as well as cooperation with the United States, without which it was difficult to sustain Yugoslav policy of equidistance towards the opposing Blocks. The fact was that both, the Yugoslav, and American officials, were partly right and partly not in their attitude. This notion contributed to calming of this dispute in the moment when the Yugoslav-Italian negotiations started, on the definitive demarcation which resulted in signing of the Osimo agreement.

${ }^{37}$ DA MSP RS, 1974, PA, SAD, f-124, 419189 i 421346. 